\title{
A Note on the 25 Most Frequent Surnames from the 2000 United States Census Bureau List
}

\author{
FRAN K NUESSEL
}

Department of Classical and Modern Languages, University of Louisville, Louisville, USA

This note uses the United States Census Bureau database of the 1,000 most frequent surnames from the US census of 2000. It discusses briefly the meaning and origin of the notion of surname. It provides a table of the 25 most frequent surnames in the US from the 2000 census data, including number of people with the surname, and its meaning. This article provides the reader with three useful onomastic research tools for surnames: (1) The US Census Bureau's list of the 1,000 most frequently occurring surnames for 2000; (2) Patrick Hanks' Dictionary of American Surnames; and (3) the National Geographic interactive surname list.

KEYWORDS census data, onomastic resources, surnames, us surname map, surname meanings.

\section{Introduction}

Morris (I979, I295) defines "surname” as “[a] person's family name as distinguished from his given name." Hanks (2003, I: xi) poses the question: "When did family names originate?" His response is that they "originated at many different times in many different places." Hanks (2003, I: xi) also notes that:

The phenomenon of the modern family name is, broadly, of medieval European origin and is associated with the rise of bureaucracies. Tax collectors, beadles and bailiffs, sheriffs and reeves (officers of law enforcement and the courts) had, like their modern counterparts, a particular need for the precise identification of individuals. In a period when the eldest son inherited property and titles, it became normal to inherit the father's surname along with other property.

The data for this note derive from the 2000 US census (United States Census Bureau 20I4). This information represents the most recent data available from the Census Bureau. 
TABLE 125 MOST FREQUENT SURNAMES IN THE US

\begin{tabular}{|c|c|c|c|}
\hline Surname & Rank & Count & Meaning \\
\hline SMITH & 1 & $2,376,206$ & $\begin{array}{l}\text { "English: occupational name for a worker in metal” (Hanks 2003, III: } \\
366-367 \text { ) }\end{array}$ \\
\hline JOHNSON & 2 & $1,857,160$ & $\begin{array}{l}\text { "English and Scottish: patronymic from the personal name JонN" (Hanks } \\
2003, \text { II: 253-254) }\end{array}$ \\
\hline WILLIAMS & 3 & $1,534,042$ & $\begin{array}{l}\text { "English (also very common in Wales): patronymic from WILLIAM" (Hanks } \\
\text { 2003, III: 615) }\end{array}$ \\
\hline BROWN & 4 & $1,380,145$ & $\begin{array}{l}\text { "English, Scottish, and Irish: generally a nickname referring to the color of } \\
\text { the hair or complexion" (Hanks 2003, I: 236) }\end{array}$ \\
\hline JONES & 5 & $1,362,755$ & $\begin{array}{l}\text { "English and Welsh: patronymic from the Middle English personal name } \\
\text { Jon(e)" (Hanks 2003, II: 255) }\end{array}$ \\
\hline MILLER & 6 & $1,127,803$ & "English and Scottish: occupational name for a miller" (Hanks 2003, II: 591) \\
\hline DAVIS & 7 & $1,072,335$ & “Southern English: patronymic from DAVID” (Hanks 2003, I: 417) \\
\hline GARCIA & 8 & 858,289 & $\begin{array}{l}\text { "Spanish (García) and Portuguese: from a medieval personal name of uncer- } \\
\text { tain origin [... It] may well be of pre-Roman origin, perhaps akin to Basque }(h) \\
\text { artz "bear" (Hanks 2003, II: 14) }\end{array}$ \\
\hline RODRIGUEZ & 9 & 804,240 & $\begin{array}{l}\text { "Spanish (Rodríguez) and Portuguese: patronymic from the personal name } \\
\text { RoDRIGO" (Hanks 2003, III: 210) }\end{array}$ \\
\hline WILSON & 10 & 783,051 & $\begin{array}{l}\text { "English, Scottish, and northern Irish: patronymic from the personal name } \\
\text { WILL, a very common medieval short form of WILLIAM" (Hanks 2003, III: 616) }\end{array}$ \\
\hline MARTINEZ & 11 & 775,072 & $\begin{array}{l}\text { "Spanish (Martínez): patronymic from the personal name MARTIN" (Hanks } \\
\text { 2003, II: 524) }\end{array}$ \\
\hline ANDERSON & 12 & 762,394 & $\begin{array}{l}\text { "Scottish and northern English: very common patronymic from the personal } \\
\text { name Ander(s), a northern Middle English form of AnDREW" (Hanks 2003, I: } \\
\text { 38) }\end{array}$ \\
\hline TAYLOR & 13 & 720,370 & "English and Scottish: occupational name for a tailor" (Hanks 2003, III: 458) \\
\hline THOMAS & 14 & 710,696 & $\begin{array}{l}\text { "English, French, German, Dutch, Danish, and South Indian: from the medie- } \\
\text { val personal name, of Biblical origin" (Hanks 2003, III: 471) }\end{array}$ \\
\hline HERNANDEZ & 15 & 706,372 & $\begin{array}{l}\text { "Spanish (Hernández) and Jewish (Sephardic): patronymic from the personal } \\
\text { name Hernando" (Hanks 2003, II: 168) }\end{array}$ \\
\hline MOORE & 16 & 698,671 & $\begin{array}{l}\text { “English: from Middle English more 'moor,' 'marsh,' 'fen,' ‘area of unculti- } \\
\text { vated land' [...] hence a topographic name for someone who lived in such a } \\
\text { place or a habitational name for any of the various places named with this } \\
\text { word” (Hanks 2003, II: 615-616) }\end{array}$ \\
\hline MARTIN & 17 & 672,711 & $\begin{array}{l}\text { “English, Scottish, Irish, French, Dutch, German, Czech, Slovak, Spanish } \\
\text { (Martín), Italian (Venice), etc.: from a personal name (Latin Martinus, a } \\
\text { derivative of Mars, genitive Martis, Roman god of fertility and war” (Hanks } \\
\text { 2003, II: 523) }\end{array}$ \\
\hline JACKSON & 18 & 666,125 & $\begin{array}{l}\text { "English, Scottish, and Northern Irish: patronymic from JACK" (Hanks } 2003 \text {, } \\
\text { II: 238) }\end{array}$ \\
\hline THOMPSON & 19 & 644,368 & $\begin{array}{l}\text { "English: patronymic from Tномаs. Thompson is widely distributed through- } \\
\text { out Britain but is most common in northern England and northern Ireland" } \\
\text { (Hanks 2003, III: 471) }\end{array}$ \\
\hline WHITE & 20 & 639,515 & $\begin{array}{l}\text { “English, Scottish, and Irish: from the Middle English whit 'white,' hence a } \\
\text { nickname for someone with white hair or an unnaturally pale complexion” } \\
\text { (Hanks 2003, III: 604) }\end{array}$ \\
\hline LOPEZ & 21 & 621,536 & $\begin{array}{l}\text { "Spanish (López): patronym from the medieval personal name Lopo (from } \\
\text { Latin lupus 'wolf')" (Hanks 2003, II: 459) }\end{array}$ \\
\hline LEE & 22 & 605,860 & $\begin{array}{l}\text { "English: topographic name for someone who lived near a meadow or a } \\
\text { patch of arable land [...] Chinese variant of LI [...] Korean variant of YI" (Hanks } \\
2003, \text { II: 413) }\end{array}$ \\
\hline GONZALEZ & 23 & 597,718 & $\begin{array}{l}\text { "Spanish (González): patronymic from the personal name GonzALo, a person- } \\
\text { al name of Visigothic origin, based on the Germanic element gunp 'battle' } \\
\text { (Hanks 2003, II: 63-64) }\end{array}$ \\
\hline HARRIS & 24 & 593,542 & $\begin{array}{l}\text { "English and Welsh (very common in southern England and South Wales): } \\
\text { patronymic from the medieval English personal name HARRY, pet form of } \\
\text { HENRY" (Hanks 2003, II: 134) }\end{array}$ \\
\hline CLARK & 25 & 548,369 & $\begin{array}{l}\text { "English: occupational name for a scribe or secretary, originally a member of } \\
\text { a minor religious order who undertook such duties" (Hanks 2003, I: 342) }\end{array}$ \\
\hline
\end{tabular}


On a website entitled "Why Is There Still No 20I0 Census Surnames Data Available?" (American Last Names 20I6), the anonymous author offers the following explanation:

Unfortunately it appears that the most recent, 20I0, USA Census results have not been processed as far as surnames are concerned. The US Census Bureau did a great job in I990 and then in 2000, processed the Census results and came up with the lists of last names in the United States. It did run out of steam when it came to the year 20I0. They have the data, they just have not got around to processing and publishing the surnames. I asked them about it to be sure. They promptly answered. Here is the US Census Bureau official response to my request on where and when the 20 Io surnames will become available.

“Thank you for using the US Census Bureau's Question \& Answer Center. Due to limited resources, there are no plans to produce any surname files from the 20 Io Census at this time."

Word et al. (20I6) provide useful information on the procedures employed by the US Census Bureau for the US Census Bureau data, and a helpful set of references.

Table I contains a list of the 25 most frequent surnames in the US for 2000 , which represents the latest data available. Column I contains the surname. Column 2 contains the numerical ranking of the name (by number of people in the US that have the surname). Column 3 contains the number of people with the surname. Column 4 contains a brief meaning of the surname derived from Hanks' (2003) three-volume Dictionary of American Family Names. Many of the entries in Hanks' dictionary contain a paragraph-length account of the origin of the family name. By referring to the US Census Bureau list of most frequent surnames in the US and Hanks' dictionary, name enthusiasts will be able to learn a great deal about family names. Table I contains selected partial citations from Hanks (2003).

\section{Discussion}

The most recent database available derives from the US census of 2000 . Although the results of the 20 Io US census data are available, the US Census Bureau does not plan to make a similar list for the data from that year because of the costs involved. This is unfortunate because the US Census Bureau surname data provide information about immigration trends.

The top 25 most frequent surnames in the US include I7 surnames that derive from the UK (\#S I, 2, 3, 4, 5, 6, 7, IO, I2, I3, I6, I7, I8, I9, 20, 24, and 25). Another two surnames (\#s I4 and I7) have a wider European domain beyond the UK. The surname LeE (\# 22) may be of English origin. However, it is also the Anglicized alphabetic spelling of the Chinese surname Li and the Korean surname Yi. Finally, six of the surnames are of Hispanic derivation (\#s 8, 9, II, I5, 2I, and 23). Given the increase in the number of Hispanics in the US based on US Census Bureau numerical data from 2010 , the number and the frequency of Hispanic surnames has likely increased. In their overview of race and Hispanic origin for 2010 Humes et al. (20II, 4) point out that, in the 2000 US census, there were $35,305,8 \mathrm{I} 8$ people of Hispanic or Latino origin ( $=_{\mathrm{I} 2} .5 \%$ of the total population). By 2010, this number had changed to $50,477,594$ (= I6.3 \% of the total population). The Pew Research Center (20I5) projects that, by $2065,24 \%$ or approximately one in every four people in the US will be of Hispanic origin. 
Another useful resource is the National Geographic Surname Map (20II), which provides the reader with the following description of its interactive surname map reproduced with the addition of capitalization added to the placenames:

This site is an exciting interactive map of surnames across the United States. This helpful map displays the most common surnames in each area, with the larger bolder ones being the most common and the smaller ones being less so. Using this map it is easy to track many interesting pieces of information besides just checking the popular names around your home. One of the most interesting opportunities this site provides is the ability to see where different ethnic groups have settled around the United States. The prevalence of English and Irish names in the mid-Atlantic, Scandinavian names in the midwest, and Latino names in the southwest states all point to very specific and fascinating settlement patterns. This is also shown in the identification of small subpopulations such as the Cuban community in southern Florida. This map also shows an interesting pattern of population density. As you might expect, names are much larger and more densely packed in the northeast, while the western states have fewer names, most of which are much smaller. In making this map, National Geographic has used geography and cartography to portray information on surname distribution in a creative, accessible way.

\section{Concluding remarks}

This note provides the reader with three important onomastic resources. First, the 2000 US Census Bureau (20I4) list provides information on the I,, 00 most frequent surnames gathered in the census that year. Second, Patrick Hanks' (2003) three-volume Dictionary of American Family Names contains succinct information about the origin and meaning of many US surnames. Finally, the National Geographic Surname Map (20I I) provides visual interactive data about the most frequent surnames in the continental US. All of these resources provide useful information on surname research. At this juncture, the US Census Bureau has no plans to produce a frequency list of surnames based on the $20 I 0$ census report. This is unfortunate because it provides a useful tool for determining ethnic and racial shifts in the population, i.e. the current Hispanic population constitutes one in every six people in the US. By 2065 , this population will likely comprise one in every four people in the US.

\section{Bibliography}

Hanks, Patrick, Ed. 2003. Dictionary of American Family Names. 3 vols. Oxford: Oxford University Press.

Humes, Karen R., Nicholas A. Jones, and Roberto R. Ramíreez. 20II. "Overview of Race and Hispanic Origin: 20Io." Accessed August Io, 20I6. http://www.census.gov/prod/cen2oIo/briefs/c2oIobr-o2.pdf

Morris, William, Ed. 1979. The American Heritage Dictionary of the English Language. Boston: Houghton Mifflin. National Geographic Surname Map. 20I I. Accessed August II, 20I6. https://blog.richmond.edu/geog250/20I I/04/28/ national-geographic-surname-map/

Pew Research Center. 20I5. "Projected U.S. Population by Race and Hispanic Origin, 2015-2065, with and without Immigrants Entering.” Accessed August 16, 20I6. http://www.pewhispanic.org/20I 5/o9/28/modern-immigrationwave-brings-59-million-to-u-s-driving-population-growth-and-change-through-2065/ph_2015-09-28_immigrationthrough-2065-a2-06/

United States Census Bureau. 20I4. Last Revised I5 September 20I4. Accessed August 8, 20I6. http://www.census. gov/topics/population/genealogy/data/2000_surnames.html 
Word David L., Charles D. Coleman, Robert Nunziata, and Robert Kominski. 20I6. "Demographic Aspects of Surnames from Census 2000.” Accessed August 8, 20I6. https://www2.census.gov/topics/genealogy/200osurnames/ surnames.pdf

American Last Names. 20I6. "Why is There Still No 20I0 Census Surnames Data Available?” Accessed August 8, 2016. http://www.americanlastnames.us/why-there-is-no-2oIo-Census-surnames-data-available.html

\section{Notes on contributor}

Frank Nuessel is Editor of Names: A Journal of Onomastics (2008-). He was elected a member of the Academia Norteamericana de la Lengua Española in 2015. He served as President of the Semiotic Society of America (20II), and Chief Reader of AP Italian (2006-2009, 20II-20I2). He was President of the American Association of Teachers of Italian (2OI2-20I4).

Correspondence to: Frank Nuessel Department of Classical and Modern Languages, University of Louisville, Louisville, KY 40292-000I, USA. Email: fhnuesor@louisville.edu 